\title{
ANALYSIS OF THE HYPOTHETICAL POPULATION STRUCTURE OF THE SQUIRREL MONKEY (SAIMIRI OERSTEDII) IN PANAMÁ
}

\author{
Ariel R. Rodríguez-Vargas*
}

\section{INTRODUCTION}

\subsection{Taxonomy, Distribution, and Natural History}

The Central American squirrel monkey (Saimiri oerstedii) is an endemic species from the coast of the Pacific Ocean to southeast Costa Rica and southwest Panamá (Hershkovitz, 1984). Three common species (S. ustus, S. sciureus, and S. boliviensis) are found in South America and are distributed in the tropical forests of the Guayanas, the Amazon basin, the high Orinoco, and the high Magdalena (Hershkovitz, 1984). Nine taxas are distinguished at the level of subspecies, of which two correspond to the Central American species (Saimiri o. oerstedii and Saimiri o. citrinellus) (Hershkovitz 1984). In Panamá only the subspecies $S$. o. oerstedii is found. The squirrel monkey is exclusively arboreal and uses a great variety of habitat (Figure 1). It mainly exploits the lower and middle forest canopy. This primate forms the largest and most cohesive groups unlike any other Neotropical primate (Kinsey, 1997). They are mainly insectivorous and frugivorous (Kinsey, 1997).

Panamá, in spite of being the Central American nation with eight primate species, lacks information on the original and current distribution of its primates. The majority of the maps published with the distributions of the taxas of interest in Mesoamerica are considered inexact because they lack up-to-date field data (Rodríguez-Luna et al., 1996a and b). The exact distribution of the squirrel monkey was described for the first time by Rodríguez (1999a) in the southwest part of the Republic of Panamá. Bangs (1902) determined the presence of the squirrel monkey on "the lowest slopes of the Talamanca Mountain Range." Other authors, such as Bennett (1968), Baldwin and Baldwin (1971, 1972, 1976, 1981), and Rodríguez (1996b), among others, have given information about

\footnotetext{
* University of Panamá, Center for Studies of Biotic Resources (CEREB) Exact and Technology Natural Sciences Faculty. 223-0212, arielrdrz@yahoo.com.
} 


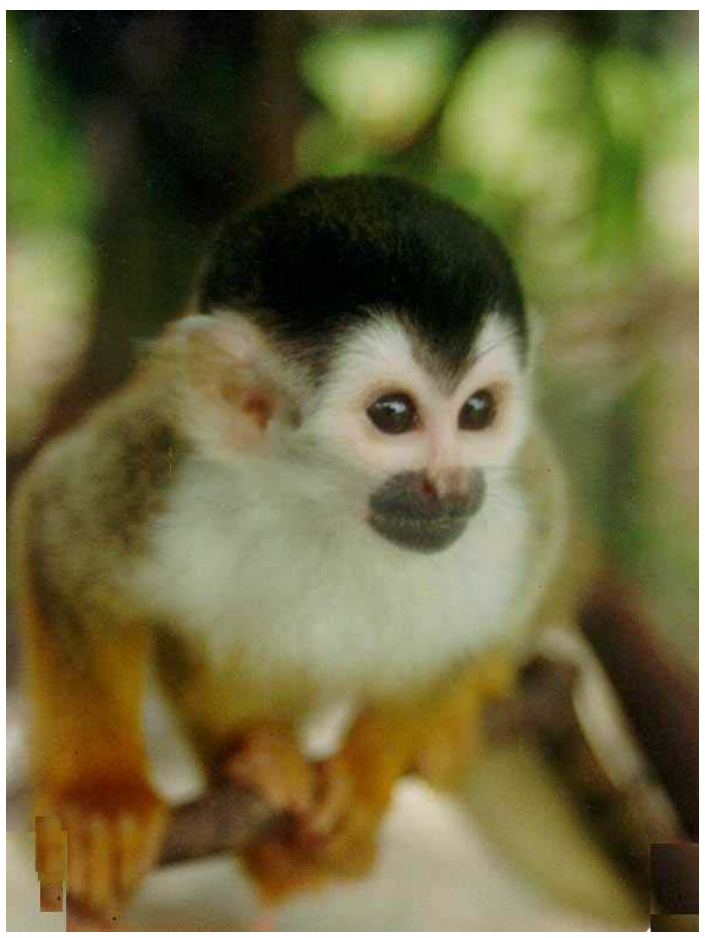

Figure 1. Juvenile Squirrel Monkey of Panamá

the presence of the squirrel monkey up to the most recent and complete data by Rodríguez (1999a and b).

Since 1970, the squirrel monkey has been included in the Threatened and Endangered species list by the U.S. Fish and Wildlife Sercvice (USDI, 1984). In 1980, the National Environmental Authority for the Republic of Panamá included this species under the category "Danger of Extinction" (RENARE, 1980). The International Union for Nature Conservation (IUCN, 1995) included it under the category of "Endangered." Since 1975 the International Agreement on Threatened Forest Species of Fauna and Flora (CITES I) has regulated the international commerce of this species (CITES, 1991). The latest revision of conservation subcategories of the IUCN (1996) for S. o. oerstedii in Panamá determined the status as "Endangered (EN)/B1+2abcde, C2a)," meaning that the taxa is confronting a high risk of extinction in their wild state in the near future. This status is characterized by their area of occupation of less than $500 \mathrm{~km}^{2}$ and their area of occurrence of less than $5,000 \mathrm{~km}^{2}$, a severely fragmented population, a notable reduction of the area and quality of the habitat, a reduction of the number of subpopulations, and a reduction of the number of reproducing individuals.

Since squirrel monkey populations are poorly studied in the region, the general objective of this chapter is to analyze, interpret, and discuss the reasons for the assignation of hypothetical population structures and their implication in strategies for the conservation and management of the squirrel monkey. 


\section{STUDY AREA}

The area includes all the extreme southeast of the Province of Chiriquí. It covers an area of approximately $3,500 \mathrm{~km}^{2}$. It includes all the territory of the following districts: Alanje, Barú, David, Renacimiento, Dolega, and Boquete and part of Bugaba (Figure 2).

\section{METHODOLOGY}

\subsection{Determination of the Metapopulations and Subpopulations}

Based on the definitions of subpopulation and metapopulation (Table 1), I used empirical evidence of movement patterns and predictions of increased movement patterns under enviromental conditions of scarce resources, and applied them to squirrel monkey's living in Chiriquí. I wish to clarify that we are dealing with population models and they should be viewed from that perspective, especially because in this study I have not been able to prove that there is an effective flux of individuals between the subpopulations

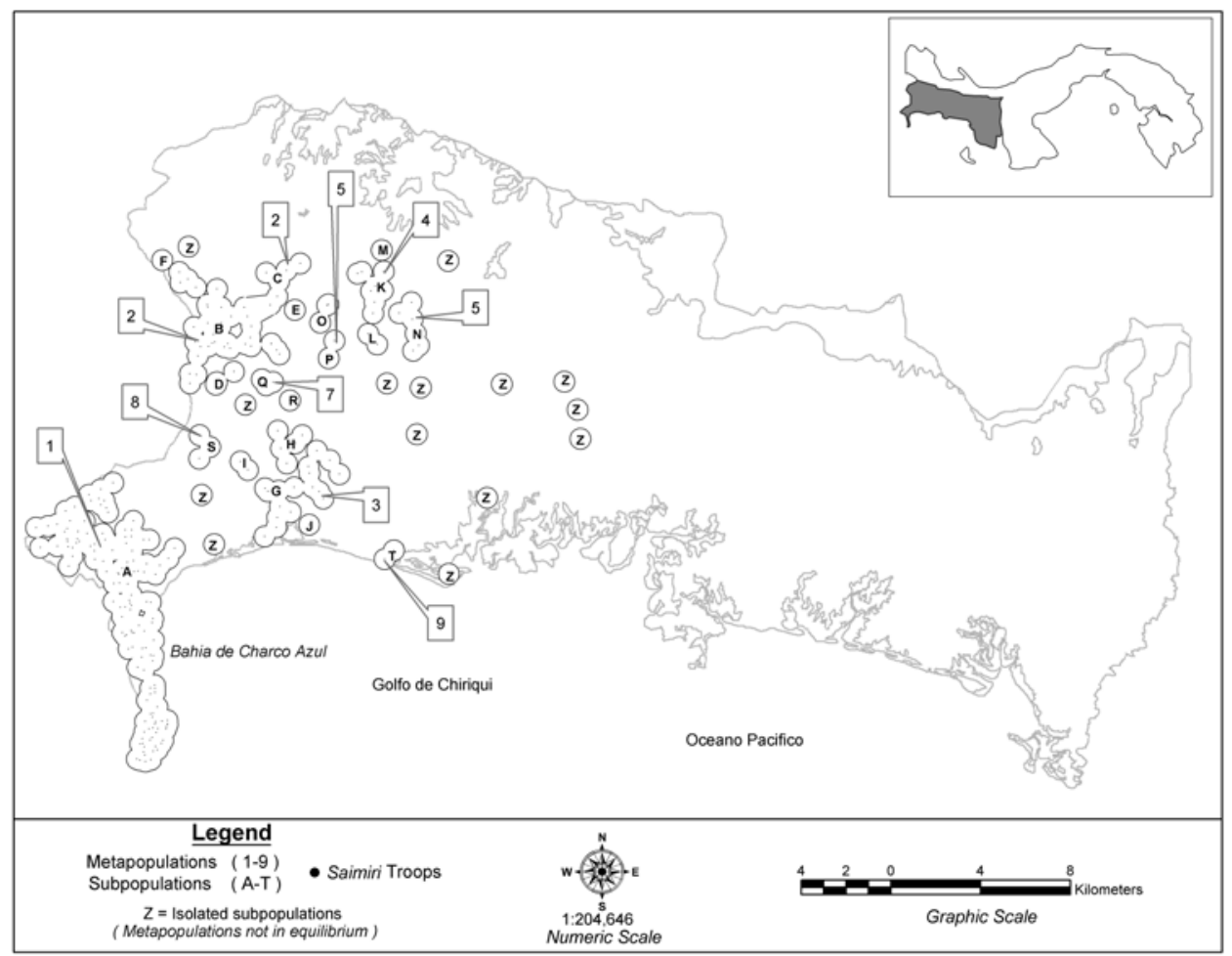

Figure 2. Location and identification of the metapopulations and subpopulations of the squirrel monkey. The distribution of this species is limited to the extreme southwest of the Isthmus of Panamá. See Table 2 to identify the name of metapopulations shown here. 
Table 1. Definitions of theoretical metapopulation classes

\begin{tabular}{|c|c|c|}
\hline $\begin{array}{l}\text { Metapopulation } \\
\text { classes }\end{array}$ & Definition & Reference \\
\hline Classic & $\begin{array}{l}\text { Population grouped in patches where there is } \\
\text { continuous recolonization and extinction. }\end{array}$ & Levins, 1970; Harrison, 1991 \\
\hline Continent & Highly connected, high population density. & Harrison, 1991 \\
\hline $\begin{array}{l}\text { Continent- } \\
\text { Continent }\end{array}$ & $\begin{array}{l}\text { Two or more large populations with high } \\
\text { density but only slightly connected. }\end{array}$ & Stith et al., 1996 \\
\hline Disjunt & $\begin{array}{l}\text { Two or more populations, small sized } \\
\text { populations, but poorly connected. }\end{array}$ & Stith et al., 1996 \\
\hline Continent-Island & $\begin{array}{l}\text { Large area with a primary population with } \\
\text { small patches around it. The population is } \\
\text { maintained through dispersal. }\end{array}$ & Harrison, 1991 \\
\hline $\begin{array}{l}\text { Subcontinent- } \\
\text { Island }\end{array}$ & $\begin{array}{l}\text { Population nucleus significant, but not large } \\
\text { enough to contribute to immigration for a long } \\
\text { term. }\end{array}$ & $\begin{array}{l}\text { New definition based on this } \\
\text { study (see discussion section) }\end{array}$ \\
\hline Subcontinent & $\begin{array}{l}\text { Population large and stable but virtually } \\
\text { isolated. }\end{array}$ & Stith et al., 1996 \\
\hline Island & $\begin{array}{l}\text { Very small and highly isolated population (in } \\
\text { the case of squirrel monkey this means at least } \\
\text { two troops). }\end{array}$ & $\begin{array}{l}\text { New definition based on this } \\
\text { study (c.f. Section 5) }\end{array}$ \\
\hline Island-Island & $\begin{array}{l}\text { Very small and highly isolated population, } \\
\text { poorly connected to another very small and } \\
\text { highly isolated population. }\end{array}$ & $\begin{array}{l}\text { New definition based on this } \\
\text { study (c.f. Section 5) }\end{array}$ \\
\hline Semi-Island & $\begin{array}{l}\text { Small isolated population, similar to a "true" } \\
\text { island condition. }\end{array}$ & $\begin{array}{l}\text { New definition based on this } \\
\text { study (c.f. Section 5) }\end{array}$ \\
\hline Non-equilibrium & $\begin{array}{l}\text { Very tiny populations completely isolated with } \\
\text { high risk of extinction in the immediate future. }\end{array}$ & Harrison, 1991 \\
\hline
\end{tabular}

within a metapopulation. Thus, I calculate the probable population conformation of the squirrel monkey in Panamá.

Through the use of the program ARCVIEW, Version 3.0 (ESRI, 1990), I determined the probable maximum radius for the dispersal of individuals in each one of the Chiriquí troops. I used 257 georeferenced points corresponding to the local groups and calculated the model with the "buffer area" command. The maximum radius of range for all squirrel monkeys in Central America was used as a reference. According to a long-term study in Corcovado National Park (PNC), Costa Rica, Boinski (1987) found that squirrel monkeys in a continuous forest area utilized a maximum range of 176 hectares. I increased the radius of dispersion by $35 \%$ ( 238 hectares) to delimit the expected maximum range of dispersion of a troop or individuals for the conformation of a subpopulation structure. This assumption was based on the data on maximum and minimum perimeters of range determined for this species by Boinski (1987) at the PNC and by Wong (1990a and b) at the Manuel Antonio National Park (PNMA).

If a squirrel monkey troop increased their range by an average of $35 \%$, then given the current conditions of discontinuous and disturbed forest cover, I hypothesize Panamá lacks two-thirds of the vital resources for their survival with respect to the areas of 
Corcovado and Manuel Antonio. Depending on the severity of fragmentation, a troop may not be able to cohesively recolonize available patches of habitat. If even one individual from a troop can move between subpopulations, even sporadically, the hypothesized principle would be achieved for the metapopulation theory of sporadic immigrations (Levins, 1970; Hasting and Harrison, 1994; Hanski 1996).

The total squirrel monkey population in Panamá is approximately 4,755 individuals wihtin 2,613.41 $\mathrm{km}^{2}$. The mean troop size for squirrel monkeys in Panamá is 18.5 individuals, with a range between 4 to 40 (Rodríguez, 1999b). Wong (1990b) reported a mean of 41 individuals per troop in Pacific Central, Costa Rica. However, Bionski and Sirot (1997) a minimal critical value for squirrel monkey troop size is 15 individuals. To make estimates of population density for subpopulations and metapopulations, the average for combined troops in Panamá was used. Rodriguez $1999^{\mathrm{a}}$ found sex and age structurs on average to be $33 \%$ male (5.8 individuals), $45 \%$ female (7.9), $14 \%$ juveniles (2.4), and 9\% infants (1.5). For this study, however, I followed Boinski and Sirot (1997) who suggest a normal troop should have $10 \%$ males, $40 \%$ females, $25 \%$ juveniles, and $25 \%$ infants.

\section{RESULTS}

Based on the spatial and distance distributions among troops, 23 metapopulations were distinguished, of which 14 corresponded to isolated tropos The metapopulations ranged between two to 139 troops (Figure 2). In the same way, a total of 34 subpopulations were identified, including the 14 isolated troops. The three main subpopulations ("A," "B," and "C") are, at the same time, the nucleus of the three main metapopulations of Chiriquí (Figure 2).

The metapopulations with the largest number of troops are those in Burica, Renacimiento, Alanje, Boquerón, and David, respectively. Of these, only the first two have 800 or more adult, juvenile, and infant individuals (Table 2).

Table 2. Characterization of the squirrel monkey metapopulations in Panamá.

\begin{tabular}{llcccc}
\hline Metapopulation* & Structure $\dagger$ & Subpopulation & No. troops & Population & $\begin{array}{c}\text { Density } \\
\text { (ind./km }\end{array}$ \\
\hline Burica (1) & Continent & 1 & 139 & 2572 & 8.37 \\
Renacimiento (2) & Continent-Island & 5 & 48 & 888 & 4.3 \\
Alanje (3) & Subcontinent-Island & 4 & 25 & 463 & 3.33 \\
Boquerón (4) & Subcontinent-Island & 3 & 11 & 204 & 3.46 \\
David (5) & Subcontinent & 1 & 6 & 111 & 3.29 \\
Concepción (6) & Island-Island & 2 & 5 & 93 & 3.18 \\
Gariché (7) & Island-Island & 2 & 4 & 74 & 3.58 \\
Jacú (8) & Semi-island & 1 & 3 & 56 & 2.81 \\
Guarumal (9) & Island & 1 & 2 & 36 & 3.9 \\
Isolated Troops & Non-equilibrium & 1 & 14 & 259 & \\
$*$ The bold numbers identify each metapopulation in Figure 2. † See text definitions and references in Table 1. \\
Subpopulation and No. troops indicated the total of geo-referenced troops within each metapopulation buffer \\
area.
\end{tabular}


With respect to the estimated number of adult individuals for each metapopulation, only that of Burica was larger than 1,000 individuals. The rest of the metapopulations did not exceed 500 adult individuals. The metapopulation with the greatest population density is Burica with 8.37 individuals $/ \mathrm{km}^{2}$, followed by Renacimiento (4.30), Guarumal (3.90), Gariché (3.58), Boquerón (3.46), Alanje (3.33), David (3.29), Concepción (3.18), and Jacú (2.81). The rest of the metapopulations correspond to isolated troops with a density of 2.60 individuals $/ \mathrm{km}^{2}$. As for the subpopulations density, only seven exceed 3.50 individuals $/ \mathrm{km}^{2}$, these are: A (9.49), B (4.88), Q (4.11), T (3.90), K (3.84), O (3.75), and $\mathrm{G}$ (3.55) (Figure 2).

\section{DISCUSSION}

The application of the concept of metapopulation is important for this study according to the criteria by Wiens (1996) because it includes two ecological realities: (1) the fragmentation of the habitat system occupied and the subdivided spatial pattern of the population and (2) the prediction of a metapopulation structure that can increase the persistence of the population as a whole, in spite of the fact that many subpopulations may have disappeared. From the point of view of conservation biology, the application of the metapopulation concept should be applied to reduced populations so that their management will ensure the probability of surviving stochastic events (Gilpin and Soulé, 1986; Gilpin, 1987; Hanski, 1991). Metapopulation management strategies should involve the management of the subpopulations to maximize the probability of survival of the species (Hanski, 1991). For this reason, I firmly believe that metapopulations and subpopulations, because of their characteristics and population size, should be considered as units for management and conservation.

According to the subpopulation and metapopulation models described in the methodology, the population of the squirrel monkey in Panamá is made up of subpopulations and metapopulations where three zones stand out as priorities for the conservation of the species: the Península of Burica, Renacimiento, and Alanje, in spite of the fact that this study did not determine the real possibilities of migration between subpopulations.

Under this focus, the metapopulation of Burica, identified as "continent metapopulation," with a large number of troops is a population that may have better opportunities of survival in the long run in the Panamanian territory, if a plan for conservation for the short- or medium-term is established in this zone. Given the pattern of grouping as a single unit, I have defined it as a continent metapopulation, which means that the population is large and is grouped together in a compact way with one or no peripheral subpopulations.

The subpopulations at Renacimiento are in danger in the short-term of suffering from increased fragmentation of the population. There is a strong tendency for isolation of the peripheral groups within the subpopulation nucleus "B" (Figure 2). Therefore, it is important that population dynamic studies of the squirrel monkey in this zone be established. Based on the theory, these subpopulations seem to behave themselves as a typical continent-island metapopulation would, defined by Harrison (1991) as a system of habitat fragments located within a dispersion distance of a large habitat fragment (continent) where the local populations are never extinguished. In this system we could include the theory of "drain-source" where the habitat (Pulliam, 1988), populations 
(Howe et al., 1991), and continent fragment (Stith et al., 1996) has individuals arriving at the peripheral fragments, in spite of the fact that these may be constantly extinguished.

The conformation of the metapopulation of Alanje, although it seems compact, is a population highly affected by the intensive use of the soil that has provoked the almost complete disappearance of the forests that would allow a dynamic interaction of the troops present in the area. It is probable that there is little or no interaction among troops; thus, it would be important to establish immediate studies and plans for monitoring to try to save this population in Chiriquí. These troops could function as a metapopulation that I have called "subcontinent-island" by considering that the subpopulation nucleus is significant, but not sufficiently large enough to maintain a contribution in the long term of individuals immigrating toward the peripheral subpopulations.

The metapopulation of Boquerón I have also considered a subcontinent-island. The metapopulation of Davíd is considered as only a "subcontinent" (Stith et al., 1996), similar to that of Boquerón but lacking in peripheral subpopulations. The metapopulation of Concepción is called "island-island" because it behaves like two isolated subpopulations, very close to each other but with a moderate probability of interchange of individuals.

For its part, the metapopulation of Jacú has been called "semi-island," since, in spite of being made up of three troops, it is a virtually isolated population. A more detailed examination of this population indicates that a high probability of an absence of metapopulation dynamics exists since the troops find themselves isolated from each other by the Río Chiriquí Viejo and Río Jacú. In spite of that, it can be called metapopulation according to the empirical criteria of Harrison (1994); a group of conspecific populations, possibly, but not necessarily, interconnected. This concept is significant because the effects of fragmentation may not diminish viability as compared to originally continuous population (Harrison, 1994). Finally, the metapopulation of Guarumal can be described as an "island" according to my criteria, based on the exclusively arboreal behavior of the squirrel monkey. This is a reduced population limited to a small area, since the landscape corresponds to an inadequate matrix for displacement and interconnection with other populations. This population has a high risk of extinction and will increase the gap between occidental and oriental populations of this species in Chiriquí.

All isolated troops I have considered are unstable metapopulations according to the criteria of Harrison (1991). Unstable populations are defined as those populations whose rate of extinction, over the long run, exceeds the rate of colonization or vice versa. An extreme case is where the local populations are so far from each other that there are no migrations between them and there are no possibilities for recolonization (Hanski and Simberloff, 1997). Brown (1987) argues that the rate of recolonization is inversely proportional to the distance that separates the isolated populations. In Chiriquí, this criteria effectively operates, given the considerable distance that separates the unstable metapopulations.

Shaffer (1981) argues that the additional problems confronting the isolated troops is an effect of the aggressive matrix of pastures and human settlements. For squirrel monkeys this means internal changes of the squirrel monkey population and high sensitivity to external pressures, leading the squirrel monkey population to a potential local extinction. These points from Shaffer should be taken seriously, particularly when deciding priorities for the relocation of troops.

Determining the locations and characteristics of the squirrel monkey population in Chiriquí may allow for a more efficient management system for forest and primate. 
However, under the current ecological and socioenviromental context of the province, it is not feasible to include the total population and its distribution within a conservation plan. Even if the plan was ideal, it is not always the most practical, given the variety of interests and economic resources required for a project of this magnitude. I propose that the biological conservation criteria of Wiens (1996) is adopted for the region. He established that the concept of metapopulation is useful for the design and management of reserves because it emphasizes explicit spatial relations, the importance of dispersion, and structure of the landscape. For reasons of sociopolitical nature, it is not always possible to apply these concepts to the "real world," but one should make the attempt.

Although this chapter determines those metapopulations which may be the most vulnerable over time, it is important to continue research on those populations while establishing conservation and management plans. In particular, research into the amount of connectedness and population migration would be a priority. Modeling lays the groundwork for field investigation, but without further data on population interactions, conservation priorities for even isolated populations becomes difficult.

\section{CONCLUSION}

The total squirrel monkey population in Panamá is minimal with just under 4,755 individuals. Its density reflects a notable shrinking of the population and a probable extinction of the greater part of their small distribution in Panamá. If the extrinsic adverse factors associated with human activities continue to operate, we will be faced with the gradual and continuous disappearance of the forest remnants in the region. The survival of the squirrel monkey in Panamá depends on management practices that may include restoring the habitat, relocations, and the administration of the isolated and highly reduced populations, based on the habitat requirements and on demographic characteristics of this species. Unlike what Boinski et al. (1998) suggest, in Panamá the efforts of management should have as a minimum scale of work, a metapopulation and not a local population. Burica and Renacimiento metapopulations showed a conservation priority and good management. Environmental education efforts are required. Conservation efforts in other identified metapopulations in this study should be carefully analized.

\section{SUMMARY}

This work discusses hypothetical population structures and their implication in strategies for the conservation and management of the squirrel monkey in Panamá. I used ARCVIEW 3.0, where I found a total of 23 metapopulations and 34 hypothetical subpopulations. The most numerous in individuals were as follows: Burica, with one subpopulation, Renacimiento, with five subpopulations, Alanje, with four subpopulations, Boquerón, with three subpopulations, and David, with one subpopulation. The rest of the population consists of isolated troops. From these abovementioned populations, only the first ones have more than 800 individuals (adults, juveniles, and infants), but only the population of Burica has more than 1,000 adult individuals. All the other hypothetical population structures have less than 500 adult individuals. The density of the hypothetical metapopulation structures are the following 
(individuals $/ \mathrm{km}^{2}$ ): Burica-8.37, Renacimiento-4.30, Guarumal-3.90, Gariché-3.58, Boquerón-3.46, Alanje-3.33, David-3.29, Concepción-3.18, and Jacú-2.81. In agreement with the theoretical analysis of the probable structure and dynamics of hypothetical metapopulations identified in Panamá, I believe that the population of Burica behaves as would a typical "continental" metapopulation, Renacimiento as a "continent island," Alanje and Boquerón as "subcontinent islands," David as a "subcontinent," Concepción as an "island island," Gariché as an "island island," Jacú as a "semi-island," Guarumal as an "island," and the rest of the isolated troops as "nonequilibrium." The development of this population model allows us to describe and prioitize conservation efforts and management of the squirrel monkey in Panamá.

\section{ACKNOWLEDGMENTS}

My thanks to G. Wong (PRMVS), E. Rodríguez-Luna (IPS), H. Chaves (PRMVS), E. Vargas (PRMVS), R. Samudio (STRI), A. Taymes (U. P.), N. Zamora (DAAD), W. VanSickle (IDEA WILD), W. Quintero (UNACHI), M. Araya (UNA), M. McCoy (PRMVS), R. Montagne (PRMVS), and the IX PRMVS Team for your help and advice. I also thank Conservation International, DAAD, IDEA WILD, Universidad de Panamá, International Primatological Society, and World Preservation Trust International for their financial support to squirrel monkey research in Panamá.

Finally I thank L. Marsh and the editor team of "Primates in Fragments" book for yours comments and edits to the manuscript.

\section{REFERENCES}

Baldwin, J. D., and Baldwin, J. I., 1971, Squirrel monkeys (Saimiri) in natural habitats in Panamá, Colombia, Brasil, and Peru, Primates 12(1):45-61.

Baldwin, J. D., and Baldwin, J. I., 1972, The ecology and behavior of squirrel monkeys (Saimiri oerstedi) in a natural forest in western Panama. Folia Primatol. 18:161-184.

Baldwin, J. D., and Baldwin, J. I., 1976, Primate population in Chiriquí, Panamá, in: Neotropical Primates Field Studies and Conservation, R. W. Thorington and P. G. Heltne, eds., National Academy of Sciences, Washington, DC, pp. 20-31.

Baldwin, J. D., and Baldwin, J. I., 1981, The squirrel monkeys, genus Saimiri, in: Ecology and Behavior of Neotropical Primates, Volume I, A. Coimbra-Filho and R. A. Mittermeier, eds., Academia Brasileira de Ciencias, Rio de Janeiro, Brasil, pp. 277-330.

Bangs, O., 1902, Chiriqui mammalia, Bulletin of the Museum of Comparative Zoology, 39(2):15-51.

Bennett, C., 1968, Human influences on the zoogeography of Panama, Iberoamericana 51:1-121.

Boinski, S., 1987, Habitat use by squirrel monkey (Saimiri oerstedi) in Costa Rica, Folia Primatol. 49:151-167.

Boinski, S., and Sirot, L., 1997, Uncertain conservation status of squirrel monkeys in Costa Rica, Saimiri oerstedi oerstedi and Saimiri oerstedi citrinellus, Folia Primatol. 68:181-193.

Boinski, S., Jack, K., Lamarsh, C., and Coltrane, J. A., 1998, Squirrel monkeys in Costa Rica: drifting to extinction, Oryx 32(1):45-58.

Brown, A., 1987, Aplicación de estudios ecológicos en la cría y conservación de primates, Boletín Primatológico Argentino 5(1):133-145.

CITES, 1991, Species listed on CITES appendices summary, Convention on International Trade in Endangered Species of Wild Fauna and Flora, Compiled by P. Biber, Secretary of Convention, Basel, Suiza.

ESRI, 1990, Understanding SIG, Enviromental Systems Research Institute, Redlands, California, USA

Gilpin, M. E., 1987, Spatial structure and population vulnerability, in: Viable Populations for Conservation, M. E. Soule, ed., Cambridge University Press, Cambridge, pp. 125-139. 
Gilpin, M. E., and Soule, M. E., 1986, Minimun viable populations: processes of species extinction, in: Conservation Biology: the Science of Scarcity and Diversity, M. E. Soule, ed., Sinauer Associates Press, MA, USA, pp. 19-34.

Hanski, I., 1991, Single-species metapopulation dynamics: concepts, models, and observations, Biological Journal of the Linnean Society 42:17-38.

Hanski, I., 1996, Metapopulation ecology, in Population dynamics in ecological space and time, Q. E. Rhodes, Jr., R. K. Cheser y, and M. H. Smith, eds., University of Chicago Press, Chicago, USA, pp. 13-43.

Hanski, I., and Simberloff, D., 1997, The metapopulation approach, its history, conceptual domain, and application to conservation, in: Metapopulation Biology, Ecology, Genetics, and Evolution, I. Hanski and M. E. Gilpin, eds., Academic Press, San Diego, CA, USA, pp. 5-26.

Harrison, S., 1991, Local extinction in a metapopulation context: an empirical evalutation, Biological Journal of the Linnean Society 42:73-88.

Harrison, S., 1994, Metapopulations and conservation, in: Large-Scale Ecology and Conservation Biology, P. J. Edwards, R. M. May, and N. R. Webb, eds., Oxford Blackwell, USA, pp. 111-128.

Hasting, A., and Harrison, S., 1994, Metapopulation dynamics and genetics, Annual Review and Ecology Systematic 25:167-188.

Hershkovitz, P., 1984., Taxonomy of squirrel monkeys genus Saimiri (Cebidae, Platyrrhini): a preliminary report with description of a hitherto unnamed form, Am J Primatol. 7:155-210.

Howe, R. W., Davis, G. J., and Mosez, V., 1991, The demographic significance of "sink population,” Biological Conservation 57:239-255.

IUCN, 1995, 1994 IUCN red list of threatened animals, WCC, IUCN Species Survival Commission and Bird Life International, B. Groombridge, ed.

IUCN, 1996, 1996 IUCN red list of threatened animals, Unión Internacional para la Conservación de la Naturaleza, Gland, Suiza, J. Baillie and B. Groombridge, eds., 368 pp.

Kinsey, W. G. (ed.), 1997, New World Primates: Ecology, Evolution, and Behavior, Aldine de Gruyter, New York, $436 \mathrm{pp}$.

Levins, R., 1970, Extinction, in: Some Mathematical Problems in Biology, M. Gerstenhaber, ed., American Mathematical Society, Providence, USA, pp. 75-107.

Pulliam, R. H., 1988, Sources, sinks, and population regulation, The American Naturalist 132:652-661.

RENARE, 1980, Lista de fauna en peligro de extinción en la República de Panamá, Ministerio de Desarrollo Agropecuario, Dirección Nacional de Recursos Naturales, Panamá.

Rodríguez, A. R., 1996, Los mamíferos amenazados de Panamá, El Universal de Panamá (A-7, 5 Septiembre), Panamá.

Rodríguez, A., 1999a, Estatus de la población y hábitat del mono tití, Saimiri oerstedii, en Panamá, Tesis de Maestría, PRMVS, Universidad Nacional, Costa Rica.

Rodríguez, A., 1999b, Modelos poblacionales del mono ardilla en Panamá como herramientas de conservación, Resumen, XVII Congreso Científico Nacional (4-8 Octubre 1999), Universidad de Panamá, Panamá.

Rodríguez-Luna, E., Cortés-Ortiz, L., Mittermeier, R., Rylands, A., Carrillo, E., Wong, G., Matamoros, F., and Nuñez Motta, J., 1996a, Hacia un plan de acción para los primates mesoamericanos, Neotropical Primates 4(Suplemento):119-133.

Rodríguez-Luna, E., Cortez-Ortiz, L., Mittermeier R., and Rylands, A., 1996b, Plan de Acción para los Primates Mesoamericanos, Grupo Especialista en Primates-Sección Neotropical. Xalapa, Veracruz, México. Borrador de Trabajo. 102 pp. +19 de anexos.

Shaffer, M. L., 1981, Minimum population sizes for species conservation, Bioscience 31:131-134.

Stith, B. M., Fitzpatrick, J. W., Woolfenden, G. E., and Pranty, B., 1996, Classification and conservation of metapopulations: a case study of the Florida scrub jay, in: Metapopulations and wildlife conservation, D. R. McCullough, ed., Island Press, Washington, USA, pp. 187-215.

U. S. Department of the Interior, 1984, Endangered and threatened wildlife and plants. U. S. Goverment Printing Office, Washington, USA. 24 pp.

Wiens, J. A., 1996, Wildlife in patchy environments: metapopulations, mosaics, and management, in: Metapopulations and wildlife conservation, D. R. MacCullough, ed., Islands Press, Washington D.C., USA, pp. 53-84.

Wong, G., 1990a, Uso del hábitat, estimación de la composición y densidad poblacional del mono tití (Saimiri oerstedi citrinellus) en la zona de Manuel Antonio, Quepos, Costa Rica, Tesis de Maestría, Programa Regional en Manejo de Vida Silvestre, Universidad Nacional, Heredia, Costa Rica, 78 pp.

Wong, G., 1990b, Ecología del mono tití (Saimiri oerstedi citrinellus) en el Parque Nacional Manuel Antonio, Costa Rica, Tesis de Grado, Universidad Nacional, Heredia, Costa Rica, 57 pp. 